\title{
Controlled trial of maintenance cimetidine treatment in healed duodenal ulcer: short and long-term effects
}

\author{
M. W. DRONFIELD, A. J. BATCHELOR, W. LARKWORTHY, AND \\ M. J. S. LANGMAN \begin{abstract}
Nocton Hall, Lincoln
\end{abstract} \\ From the University Department of Therapeutics, City Hospital, Nottingham, and RAF Hospital,
}

SUMMARY Forty-two patients with endoscopically diagnosed duodenal ulcer were studied in a double-blind trial after their ulcers had been healed with cimetidine. Cimetidine was effective in preventing relapse, only five of the 20 patients allocated to cimetidine $400 \mathrm{mg}$ twice daily relapsing during the six months' treatment, compared with 16 of the 22 on placebo treatment $(P<0.01)$. Cimetidine was safe in the dosage and duration used, no symptomatic, haematological, or biochemical abnormalities occurring during the trial. Subsequent follow-up at the end of the trial when treatment had been stopped showed that relapse was frequent, particularly in the cimetidine group, making the cumulative relapse rate eight months after completion of the trial similar in the two groups (75\% in the cimetidine group; $86 \%$ in the placebo group). It seems likely that maintenance cimetidine treatment has to be continued indefinitely in patients with duodenal ulcer, and, until such treatment is shown to be safe and effective, surgical treatment remains a logical option for many patients.

Duodenal ulcer is commonly a remitting and relapsing condition over many years and it follows that medical treatment should probably be prolonged to be effective. Cimetidine heals duodenal ulcers in the short term (Gray et al., 1977; Multicentre Trial, 1979), but relapse often occurs rapidly on stopping treatment (Gray et al., 1977). We have compared cimetidine $400 \mathrm{mg}$ twice daily with placebo in a double-blind trial over six months in patients whose duodenal ulcers healed during cimetidine treatment, and have followed up the relapse-free patients after they completed the trial.

The aims were to see if cimetidine taken in this way is safe and effective, and to determine if continued cimetidine treatment would prolong remission once treatment was stopped.

\section{Methods}

Forty-four adult outpatients entered the trial. All had had a symptomatic duodenal ulcer diagnosed endoscopically within three months of starting the maintenance trial. In each patient symptoms had remitted and endoscopy at the beginning of the maintenance trial had shown that the ulcers had

Received for publication 19 February 1979 healed. In all but one of the patients healing was achieved with cimetidine in a dose of 1 or $2 \mathrm{~g}$ daily for between one to three months. Patients with a second disease likely to cause abdominal pain, those with renal, hepatic, or severe cardiorespiratory disease, and women who might be pregnant were excluded from the study.

The trial was double-blind and patients were allocated by the pharmacist using a prearranged randomised schedule to either cimetidine $400 \mathrm{mg}$ twice daily or an identical placebo. Patients were seen monthly for six months or until a relapse of symptoms occurred. At each visit enquiry was made as to whether any dyspeptic symptoms or adverse reactions had developed and blood was taken at most visits for haematological and biochemical analyses. If symptoms returned the patient was endoscoped and the trial discontinued, relapse being defined as a return of typical daily ulcer dyspepsia for at least one week or a major complication such as acute bleeding. Endoscopy was performed using an end-viewing instrument by a physician who was aware of the symptomatic state of the patient.

Patients who were asymptomatic at the end of six months' trial treatment were usually not endoscoped; the treatment was stopped and outpatient follow-up arranged. However, six asymptomatic patients (four 
on cimetidine, two on placebo) were endoscoped at the end of the trial because of Armed Forces commitments and two of these (one on cimetidine, one on placebo) were found to have duodenal ulceration. They were therefore considered to have relapsed at six months, but exclusion of these two patients would have very little effect on the overall results. The patients who discontinued the trial treatment after six months without symptoms were endoscoped whenever practicable if relapse occurred.

\section{Results}

Twenty-two patients were randomly allocated to placebo treatment, and 22 to cimetidine. Two patients in the cimetidine group were withdrawn from the study, one being lost to follow-up after completing three months without symptoms and one developed new symptoms early in the trial because of biliary colic and required cholecystectomy. The remaining 20 patients in the cimetidine group were similar to the 22 in the placebo group with regard to age, sex, smoking habits, previous history, and recent treatment (Table 1).

Table 1 Comparability of the two groups of patients

\begin{tabular}{|c|c|c|}
\hline & $\begin{array}{l}\text { Cimetidine } \\
(n=20)\end{array}$ & $\begin{array}{l}\text { Placebo } \\
(n=22)\end{array}$ \\
\hline $\begin{array}{l}\text { Mean age (yr } \pm \text { SD) } \\
\text { Sex } \\
\text { Number of cigarette smokers } \\
\text { Mean total duration of } \\
\text { symptoms in years (range) } \\
\text { Mean duration of recent } \\
\text { attack in months (range) } \\
\text { Previous haematemesis } \\
\text { Previous perforation } \\
\text { Cimetidine in } 3 \text { months before } \\
\text { trial: } \\
\quad \text { for } 1 \text { month } \\
\quad \text { for } 2 \text { months } \\
\text { for } 3 \text { months } \\
\text { Antacids only }\end{array}$ & $\begin{array}{l}43.4( \pm 11 \cdot 9) \\
\text { M. } 18 ; \text { F. } 2 \\
16 \\
7.9(0 \cdot 6-29) \\
3 \cdot 2(0 \cdot 1-12) \\
5 \\
2\end{array}$ & $\begin{array}{l}40.9( \pm 12 \cdot 8) \\
\text { M. } 19 ; \text { F. } 3 \\
16 \\
10.5(0 \cdot 5-30) \\
3.8(0 \cdot 3-12) \\
5 \\
0\end{array}$ \\
\hline
\end{tabular}

\section{RELAPSES (TABLE 2)}

Four patients treated with cimetidine suffered relapses of symptoms as defined above, in two recurrent duodenal ulcers were demonstrated endoscopically and the other two had endoscopic duodenitis without recurrent ulceration. Another patient treated with cimetidine was asymptomatic at the end of the trial, but was found to have a recurrent ulcer endoscopically (see above), making a total of five relapses in the cimetidine group.

In striking contrast 16 of the 22 patients treated with placebo relapsed, 15 with symptoms during the trial and one with an asymptomatic duodenal ulcer
Table 2 Relapses during maintenance trial

\begin{tabular}{lll}
\hline & $\begin{array}{l}\text { Cimetidine } \\
(n=20)\end{array}$ & $\begin{array}{l}\text { Placebo } \\
(n=22)\end{array}$ \\
\hline Relapse in month & 1 & \\
1 & 1 & 5 \\
2 & 1 & 2 \\
3 & 1 & 4 \\
4 & 0 & 2 \\
5 & 1 & 1 \\
6 & 1 & $16^{*}$ \\
Total relapses & $5^{*}$ & $6^{*}$ \\
Relapse-free & $15^{*}$ & \\
\hline \multirow{2}{*}{$\chi^{2}=9.55(\mathrm{P}<0.01)}$. &
\end{tabular}

at the end of six months. Of the 15 with symptomatic relapses 13 were shown endoscopically to have recurrent duodenal ulceration, one could not tolerate further endoscopy, and one had a normal duodenal cap. This latter patient's symptoms were eventually considered to be due to the irritable bowel syndrome, all other investigations being negative, but his original symptoms were most probably caused by his duodenal ulcer and had remitted promptly when his ulcer had been healed.

FOLLOW-UP OF RELAPSE-FREE PATIENTS

Twenty-one patients (15 treated with cimetidine, six with placebo) remained asymptomatic at the end of the six months' trial period. In these patients treatment was stopped and all have been followed up either until relapse or for at least eight months. Ten of the 15 cimetidine patients have suffered a relapse of symptoms between three days and eight months after discontinuing maintenance treatment. In five of these endoscopy has been performed and has shown recurrent duodenal ulceration, while in the other five additional courses of cimetidine had already been instituted on clinical grounds before we were able to carry out endoscopy. Three of the six placebo patients have also relapsed after completion of the trial, and in the two cases endoscoped a recurrent duodenal ulcer has been demonstrated. The percentage cumulative relapse rate calculated from the figures for the six months' trial treatment and the succeeding eight months is shown in the Figure. Eight months after the completion of the maintenance period the cumulative relapse rate is almost the same in both groups, being $75 \%$ in the cimetidine group and $86 \%$ in the placebo group.

\section{PREDICTION OF RELAPSE}

The previous histories of the patients who have and have not relapsed have been compared to see if it might be possible to predict which patients are likely to relapse. The eight patients who remained relapse free eight months after the end of the trial had had a rather shorter history of duodenal ulcer (mean 5.3 


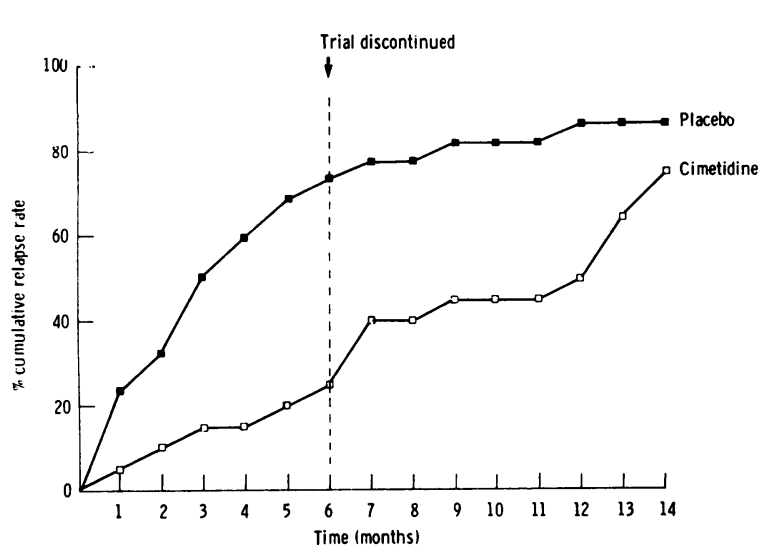

Figure Percentage cumulative relapse rate during and after trial.

years) and shorter most recent symptomatic attack (mean 1.5 months) than in the 34 who relapsed (mean 10.2 years and 3.9 months). Fourteen of the 42 patients in the study had a history of more than eight years ulcer dyspepsia, and all of these patients with long histories relapsed during or after the trial.

There were no substantial differences in the previous histories of the five patients who relapsed on maintenance cimetidine treatment and the 15 who did not.

\section{SIDE-EFFECTS}

Notroublesome symptomatic side-effects attributable to the treatment occurred in either group.

Blood samples were taken for haematology and biochemistry at the visits of both the cimetidine and placebo treated patients. No abnormal trends developed in haemoglobin concentration or white cell count. Blood films were carefully examined for morphological changes, particularly of the white cells, and minor changes such as neutrophil vacuolation or Döhle bodies were detected in $6 \%$ of samples from patients on cimetidine and $14 \%$ from patients on placebo.

Other measurements are shown in Table 3 indicating the proportion of samples in each treatment group in which abnormalities were found. Platelet counts were found to be below the normal range (150$\left.400 \times 10^{9} / 1\right)$ with equal frequency in the two groups, but in only one case, a patient on placebo, was a count below $100 \times 10^{9} / 1$ found. Cimetidine is known to increase serum creatinine levels and this we confirmed. In only $5 \%$ of samples was the increased level above $140 \mu \mathrm{mol} / 1$ and none exceeded $160 \mu \mathrm{mol} / \mathrm{l}$. There was no concomitant rise in blood urea and there were no abnormalities on urine testing. Uric acid levels were raised more often in the cimetidine
Table 3 Haematological and biochemical abnormalities occurring during treatment

\begin{tabular}{|c|c|c|}
\hline \multirow[t]{2}{*}{$\begin{array}{l}\text { Measurement } \\
\text { (normal level) }\end{array}$} & \multicolumn{2}{|c|}{$\begin{array}{l}\text { Blood samples with results outside normal range } \\
(\%)\end{array}$} \\
\hline & Cimetidine & Placebo \\
\hline $\begin{array}{l}\text { Platelets } \\
\left(>100 \times 10^{\circ} / \mathrm{l}\right) \\
\text { Creatinine } \\
(<120 \mu \mathrm{mol} / \mathrm{l}) \\
\text { Urea } \\
(<6.5 \mathrm{mmol} / \mathrm{l}) \\
\text { Uric acid } \\
(<400 \mu \mathrm{mol} / \mathrm{l}) \\
\text { Alk. phos. } \\
(<190 \mathrm{IU} / \mathrm{l}) \\
\text { SGPT } \\
(<20 \mathrm{IU} / \mathrm{l}) \\
\text { Bilirubin } \\
(<18 \mu \mathrm{mol} / \mathrm{l}) \\
\gamma \mathrm{GTP} \\
(<28 \mathrm{IU} / \mathrm{l})\end{array}$ & $\begin{array}{c}0 \\
22^{*} \\
5 \\
24 \\
0 \\
8 \\
6 \\
19\end{array}$ & $\begin{array}{l}1 \\
4^{*} \\
0 \\
7 \\
0 \\
7 \\
0 \\
7\end{array}$ \\
\hline
\end{tabular}

${ }^{*} \chi^{2}=4.33(\mathrm{P}<0.05)$. Other differences not statistically significant.

treated patients and in one case this level was above $500 \mu \mathrm{mol} / 1$. Abnormalities of liver function tests were found more commonly in cimetidine treated patients than placebo treated, mainly in levels of gamma-glutamyl-transpeptidase $(\gamma \mathrm{GTP})$, but these exceeded $50 \mathrm{IU} / 1$ in only one patient in whom high levels preceded treatment. Bilirubin levels were occasionally raised, but never above $30 \mu \mathrm{mol} / \mathrm{l}$.

Serum prolactin levels have been reported to be increased by cimetidine treatment. We measured this on 15 occasions in six patients on cimetidine between months two and six, and seven times in four patients on placebo between months one and six. We found no evidence of a raised prolactin level in the cimetidine group. In fact, the mean level in patients on cimetidine was $170 \mu / 1$ compared with $268 \mu / 1$ in the placebo group (normal range 100-400 $\mu / 1$ ).

\section{Discussion}

Our results show that after the healing of duodenal ulcers with oral cimetidine over three-quarters of patients whose treatment is stopped can expect a relapse within six months; and that this recurrence rate can be dramatically reduced by cimetidine in a dose of $\mathbf{4 0 0} \mathrm{mg}$ twice daily. Disease characteristics and behaviour in clinical trials are not always representative of those in ordinary practice, and, as the numbers of patients we have examined are small, results should be extrapolated cautiously to routine clinical work. Nevertheless, our findings are in accord with other cimetidine maintenance studies, some of which have used a maintenance dose at night only (Blackwood et al., 1978; Gudmand-Høyer et al., 1978). In our study there have been no instances of a 
catastrophic recurrence of ulceration leading to haemorrhage or perforation on cessation of cimetidine either in the placebo group or at the end of the trial in the cimetidine group, as has occasionally been reported (Saunders and Wormsley, 1977; Wallace et al., 1977). As might be expected, the few patients who did not relapse throughout the study tended to have had a shorter history of DU than those who relapsed, and it is noteworthy that all patients with a history of more than eight years ulcer dyspepsia relapsed during the study.

In our trial cimetidine proved to be a safe treatment in the dosage and for the duration it was used. It was tolerated well without side-effects in all patients and haematological abnormalities occurred no more often in cimetidine than placebo-treated patients. However, various biochemical abnormalities were found more frequently in cimetidine-treated patients, the most striking being rises in serum creatinine, uric acid, and $\gamma$ GTP, although only in the case of creatinine was this statistically significant. In no patient was there a persistent rise in these levels. Rises were often transient and none of the abnormalities was clinically significant. Rises in serum creatinine have been noted before (Sharpe and Hawkins, 1977) and do not seem to be associated with changes in renal function. Similarly, minor rises in serum liver enzyme concentrations have been noted elsewhere (Sharpe and Hawkins, 1977), but have never progressed and not been associated with clinical hepatic disease. We also found rises in serum uric acid more often in patients on cimetidine, as found by others (Multicentre Trial, 1979), but again this was mild and transient and no episodes of gout occurred.

Gynaecomastia is a rare complication of cimetidine treatment (Hall, 1976; Delle Fave et al., 1977), and it has been suggested that rises in the serum prolactin levels might be responsible (Carlson and Ippoliti, 1977; Delle Fave et al., 1977). We found no evidence of such a rise in the patients studied. Plasma levels, on average, tended to be higher in the placebo than in the cimetidine patients, but the difference was not statistically significant.

It was hoped that a prolonged course of cimetidine treatment as used in this trial would lead to prolonged remission, but follow-up of patients who completed the trial without recurrence did not show this to be the case (Figure), and it seems that the eventual outcome in patients treated with cimetidine for six months is little different to that in patients treated with placebo. These recurrence figures take no account of severity and it is impossible to predict whether the ultimate course of the disease can be altered by continued treatment. It would seem from the results shown in the Figure that the healing of duodenal ulceration with cimetidine followed by six months' maintenance treatment may confer no ultimate advantage over healing with cimetidine followed by no treatment, merely serving to postpone relapse during the treatment.

With the information currently available and bearing in mind its high cost, the crucial question is, how should cimetidine be used in patients with duodenal ulceration? In those with infrequent relapse but whose symptoms are sufficiently severe to justify its use cimetidine $1 \mathrm{~g}$ /day until endoscopically proven healing has occurred may be the best policy for each attack. For patients with frequent relapse the choice would seem to lie between continuous, perhaps indefinite cimetidine maintenance treatment or surgery. While we have not found any major side effects of cimetidine over six months' usage, its safety and efficacy in the longer term has yet to be demonstrated and, until it is, surgery still remains a logical treatment in patients with severe and frequent recurrence of duodenal ulceration, particularly in those with a long history of ulcer dyspepsia.

We are grateful to Smith, Kline and French Ltd for supplying the cimetidine and placebo tablets; and also to Staff Nurse S. Everitt and Auxiliary S. Cohen for help in following-up our patients. We are also grateful to the Director General Medical Services (RAF) for permission to undertake and report this joint study.

\section{References}

Blackwood, W. S., Maudgal, D. P., and Northfield, T. C. (1978). Prevention by bedtime cimetidine of duodenalulcer relapse. Lancet, 1, 626-627.

Carlson, H. E., and Ippoliti, A. F. (1977). Cimetidine, an $\mathrm{H}_{2}$-antihistamine, stimulates prolactin secretion in man. Journal of Clinical Endocrinology and Metabolism, 45, 367370.

Delle Fave, G. F., Tamburrano, G., De Magistris, L., Natoli, C., Santoro, M. L., Carratu, R., and Torsoli, A. (1977). Gynaecomastia with cimetidine (Letter). Lancet, 1, 1319.

Gray, G. R., McKenzie, I., Smith, I. S., Crean, G. P., and Gillespie, G. (1977). Oral cimetidine in severe duodenal ulceration. Lancet, 1, 4-7.

Gudmand-Høyer, E., Jensen, K. B., Krag, E., Rask-Madsen, J., Rahbek, I., Rune, S. J., and Wulff, H. R. (1978). Prophylactic effect of cimetidine in duodenal ulcer disease. British Medical Journal, 1, 1095-1097.

Hall, W. H. (1976). Breast changes in males on cimetidine (Letter). New England Journal of Medicine, 295, 841.

Multicentre Trial (1979). A comparison of two doses of cimetidine and placebo in the treatment of duodenal ulcer. Gut, 20, 68-74.

Saunders, J. H. B., and Wormsley, K. G. (1977). Long-term effects and after-effects of treatment of duodenal ulcer with metiamide. Lancet, 1, 765-767.

Sharpe, P. C., and Hawkins, B. W. (1977). Efficacy and safety of cimetidine. Long term treatment with cimetidine. In Cimetidine: Proceedings of the 2nd International Symposium on Histamine $\mathrm{H}_{2}$ Receptor Antagonists, pp. 358-366. 
(International Congress Series, 416). Edited by W. L. Perforation of chronic peptic ulcers after cimetidine. Burland and M. A. Simkins. Excerpta Medica: Amsterdam. British Medical Journal, 2, 865-866.

Wallace, W. A., Orr, C. M. E., and Bearn, A. R. (1977). 